\title{
Formulation and Evaluation of Fresh Red Hawaiian Hibiscus (Hibiscus rosa-sinensis) Incorporated Valued Added Products
}

\author{
Aishwarya Bahuguna ${ }^{1 *}$, K.G. Vijayalaxmi ${ }^{1}$ and V.C. Suvarna ${ }^{2}$ \\ ${ }^{1}$ Department of Food Science and Nutrition, ${ }^{2}$ Department of Agricultural Microbiology, \\ University of Agricultural Sciences, GKVK, Bangalore, 560065, India \\ *Corresponding author
}

\section{A B S T R A C T}

\begin{tabular}{|c|c|}
\hline $\mathrm{Ke}$ & \\
\hline $\begin{array}{l}\text { Edible } \mathrm{f} \\
\text { Hibiscu } \\
\text { sinensis } \\
\text { addition } \\
\text { and anti } \\
\text { properti }\end{array}$ & $\begin{array}{l}\text { rich in nutrients, and also possess antioxidant and antimicrobial properties. Hibiscus rosa- } \\
\text { sinensis is an evergreen shrub, belonging to the Malvaceae family. The present } \\
\text { investigation was aimed to enhance the consumption of Hibiscus as an edible flower in the } \\
\text { daily diet in order to exploit their nutritional benefits. The nutritional composition of fresh } \\
\text { red Hibiscus rosa-sinensis flowers was analyzed and these flowers were incorporated into } \\
\text { various products. Fresh Hibiscus rosa-sinensis flowers had } 1.54 \mathrm{~g} \text { protein and } 0.35 \mathrm{~g} \text { fat. } \\
\text { Total ash was } 1.40 \mathrm{~g} / 100 \mathrm{~g} \text {, crude fibre was } 1.50 \mathrm{~g} \text { and carbohydrate was } 13.71 \mathrm{~g} \text { per } 100\end{array}$ \\
\hline Art & $\begin{array}{l}\text { ers had } \beta \text {-carotene }(54.02 \mu \mathrm{g}) \text { and vitamin } \mathrm{C}(7.502 \mathrm{mg}) \text {. Three } \\
\text { gulkand and juice were prepared and were subjected to }\end{array}$ \\
\hline 18 & $\begin{array}{l}\text { ceptability studies. The macronutrient composition was computed and shelf life study } \\
\text { as carried out. Gulkand with } 10 \text { per cent variation and juice with } 50 \text { per cent variation } \\
\text { as found to be most acceptable. Gulkand was found to be suitable for consumption after } \\
\text { days of storage. }\end{array}$ \\
\hline
\end{tabular}

\section{Introduction}

Edible flowers have been traditionally utilized for human consumption in various cultures. They enhance the taste, appearance and aesthetic value of food. "The edible flower is defined as Non-toxic, innocuous flowers with health benefits consumed in human diet" ( $\mathrm{Lu}$ et al., 2016). There is a wide range of underutilized edible flower species which have the potential for nutritional and commercial exploitation in varied forms.
Hibiscus rosa-sinensis is commonly known as Hawaiian hibiscus or Chinese hibiscus. It is cultivated throughout India and has several forms with varying colors and flowers. All the parts of Hibiscus rosa-sinensis and their respective chemical constituents are used for their antiovultory, anti-tumor, spasmolytic, antifertility, antipyretic, hypoglycaemic, antiinflammatory, analgesic, antimicrobial, CNS depressant, and hypotensive activity (Jadhav et al., 2009). 
Value addition to food products has assumed vital importance in recent days. Value is added to the food products in order to enhance their palatability and/or nutritional value or to increase the shelf life of perishables by altering or modifying their form, color, manufacturing process and other attributes. Thus, the present investigation is an attempt to analyze the nutritional composition of fresh red Hawaiian hibiscus flowers, formulate value added products from the flowers and study their shelf life.

\section{Materials and Methods}

The raw material required for the study was procured from home gardens of farmers of Doddaballapura taluk of Bengaluru. The sepals were manually separated, the petals and stalk were washed in tap water to remove extraneous matter and finely chopped using stainless steel knife. The fresh flowers were subjected to nutrient analysis. Moisture, protein, fat, crude fiber, ash, potassium, iron and zinc were estimated following AOAC standard methods (1980). Calcium content was determined by titrating it against $0.01 \mathrm{~N}$ EDTA as described by Heau et al. (1965). The vitamin $\mathrm{C}$ concentration was determined using redox titration with potassium iodate in the presence of potassium iodide (Tauber and Kleiner, 1935). The concentration of $\beta$ carotene was measured in spectrophotometer at $450 \mathrm{~nm}$ (Ranganna, 2002). Antioxidant capacity was estimated by DPPH (2, 2diphenyl-1-picrylhydrazyl) radical scavenging activity method (Kang and Saltveit, 2002). Gulkand and juice were prepared by incorporating fresh hibiscus flower petals. Nutrient composition of the best accepted developed products was computed based on the nutritional composition of the ingredients (Gopalan et al., 2014). Shelf life study was done for the products based on sensory scores, moisture content and microbial analysis.

\section{Results and Discussion}

\section{Nutritional analysis of fresh flowers}

The results of the nutritional analysis of fresh red Hawaiian hibiscus flowers are shown in Table 1. It was found that fresh Hibiscus rosa-sinensis flowers had 83.00 per cent moisture, $1.54 \mathrm{~g}$ protein and $0.35 \mathrm{~g}$ fat. Total ash was $1.40 \mathrm{~g} / 100 \mathrm{~g}$, crude fibre was $1.50 \mathrm{~g}$ and carbohydrate was $13.71 \mathrm{~g}$ per $100 \mathrm{~g}$. Among vitamins the flowers had $\beta$-carotene $(54.02 \mu \mathrm{g})$ and vitamin $\mathrm{C}(7.502 \mathrm{mg})$. The results of mineral analysis showed that fresh flowers had $4.32 \mathrm{mg}$ of calcium, $236.45 \mathrm{mg}$ potassium, $1.48 \mathrm{mg}$ of iron and $0.82 \mathrm{mg}$ zinc. These results are comparable with the findings of Jadhav et al. (2009) who reported that the edible part of fresh Hibiscus rosasinensis flower contains $89.80 \mathrm{~g}$ of moisture, $0.064 \mathrm{~g}$ of nitrogen, $0.36 \mathrm{~g}$ of fat, $1.56 \mathrm{~g}$ of crude fibre, $4.04 \mathrm{mg}$ of calcium, $26.68 \mathrm{mg}$ of phosphorus, and $1.69 \mathrm{mg}$ of iron, $4.90 \mathrm{mg}$ ascorbic acid per $100 \mathrm{~g}$ of flowers.

Total antioxidant activity was found to be $60.12 \mathrm{mg}$ ascorbic acid equivalents/100g. Khan et al. (2014) reported the total antioxidants in methanol and ethanol extract of Hibiscus rosa-sinensis which showed total phenolics $61.45 \pm 3.23$ and 59.31 \pm 4.31 $\mathrm{mg} / 100 \mathrm{~g}$ as gallic acid equivalent, total flavonoids $53.28 \pm 1.93$ and $32.25 \pm 1.21$ $\mathrm{mg} / 100 \mathrm{~g}$ as catechine equivalent, DPPH free radical scavenging activity $75.46 \pm 4.67$ and $64.98 \pm 2.11$ per cent respectively.

\section{Formulation of value added products}

Value added products viz., gulkand, and juice were prepared from hibiscus flowers. Sensory evaluation was carried out for acceptance of the products using nine point hedonic scale by 21 semi-trained panel members. Table 2 enlists the formulation of the developed value added products from fresh hibiscus flowers. 
Traditionally gulkand has been used as a cooling tonic to combat fatigue, lathery, muscular aches, biliousness itching, and heatrelated conditions. It is good for memory and eyesight as well as a good blood purifier. Gulkand also helps reducing hyperacidity. It is also rich in calcium and has antioxidant properties (Pendawale et al., 2015). The rose flowers were substituted with hibiscus flowers in order to improve the antioxidant and nutritional quality as well as to reduce the cost of the product as rose petals are a costly ingredient.

Gulkand with 10 per cent hibiscus flowers was best accepted with highest scores of 8.19, $8.19,8.04, \quad 7.90,8.19$ and 7.90 for appearance, colour, aroma, taste and overall acceptability respectively. Control scored $8.42,8.42,8.33,8.33,8.14$ and 8.15 for appearance, colour, aroma, texture, taste and overall acceptability respectively.

Juice prepared with 50 per cent hibiscus was best accepted with highest scores of 8.57, $8.57,8.76,8.23,8.66$ and 8.76 for appearance, colour, aroma, consistency, taste and overall acceptability respectively. Control prepared with 70 per cent pineapple scored $8.57,8.61,8.28,8.19,8.28$ and 8.19 for appearance, colour, aroma, consistency, taste and overall acceptability respectively.

\section{Macronutrient composition of best accepted products}

The macronutrient composition of the best accepted and control products were computed and the results are displayed in Table 3. In gulkand there was not much difference in the macronutrient composition between HGL1 and control which is probably due to the similar macronutrient composition of rose and hibiscus flowers. However, the ash content reduced from $0.99 \mathrm{~g}$ to $0.24 \mathrm{~g}$ in HGL1 compared to control.

\section{Shelf life study of the developed products}

Gulkand was packed in glass jars and kept at room temperature. Sensory attributes, moisture content and microbial population were observed at an interval of 30 days i.e. initial, 30th and 60th day for chocolates and gulkand. Shelf life study for juice was not conducted as it is meant to be consumed fresh.

The results of the mean sensory score evaluation of gulkand from initial day to 60 days of storage study period are presented in the Table 4. Decrease in the sensory score was observed during storage period. The control sample showed scores of 8.04, 8.00, $7.95,7.95,7.76$ and 7.71 for appearance, colour, texture, aroma, taste and overall acceptability respectively, whereas the HGL1 (10 per cent) variation had mean sensory scores of 8.00 (appearance), 7.61 (texture), 7.90 (colour), 7.76 (aroma), 7.90 (taste) and 7.66 (overall acceptability) after 60 days of storage studies. Control was more acceptable after storage than variation HGL1. It was evident from the sensory scores that, even after 60 days of storage period both the products viz., control and HGL1 were acceptable. There was a decline in the sensory score of colour and appearance for both the samples as the fresh product samples had a bright red color, because of more anthocyanins which may have gradually decreased on storage leading to colour fading and less attractive colour and appearance. Anthocyanins are said to turn into brown pigment as a result of decomposition.

These results were in accordance with general findings that monomeric pigment concentrations decrease during storage (Withy et al., 1993). Similar results of decrease in sensory scores were reported for strawberry jam by Kimura et al., (1994) where room temperature storage resulted in 
rapid deterioration including off-flavor, discoloration, browning.

This deterioration in flavour may be attributed to the decomposition of sucrose in gulkand caused by organic acids and enzymes. Similar results on the effect of storage time and temperature $\left(5^{\circ} \mathrm{C}\right)$ on apricot jams were reported by Touati et al. (2014) where the scores for taste reduced from 7.56 on day 0 to 7.00 after 60 days of storage.

Microbial population (bacteria, moulds and coliforms) of control and best accepted variations of developed products was estimated using standard plate count method on initial, $30^{\text {th }}$ and $60^{\text {th }}$ days and are depicted in Table 5 and Figure 1. The total bacterial population on $60^{\text {th }}$ day was $3.60 \times 10^{2} \mathrm{cfu} / \mathrm{g}$ and $2.93 \times 10^{2} \mathrm{cfu} / \mathrm{g}$ for control and HGL1 respectively. The mould population was $0.06 \times 10^{2} \mathrm{cfu} / \mathrm{g}$ for control on initial day which was increased to $1.33 \times 10^{2} \mathrm{cfu} / \mathrm{g}$ during 60 days of storage. For HGL1, the mould population was $0.13 \times 10^{2} \mathrm{cfu} / \mathrm{g}$ on initial day and $1.16 \times 10^{2} \mathrm{cfu} / \mathrm{g}$ on day 60 . Escherichia coli was absent in control on initial day and grew to $0.53 \times 10^{2} \mathrm{cfu} / \mathrm{g}$ during the storage period of 60 days. In HGL1 samples, Escherichia coli population increased from $0.13 \times 10^{2} \mathrm{cfu} / \mathrm{g}$ to $0.50 \times 10^{2} \mathrm{cfu} / \mathrm{g}$ during 60 days of storage.

As number of days of storage increased there was an increase in microbial growth. High water availability and sugar content may be the factors responsible for the increase in the microbial population. As per results, gulkand was fit for consumption up to 60 days. Similar results were reported by Sindumathi and Amutha (2014) where an increasing trend in bacterial and fungal population was observed in stored coconut based jam throughout the storage period.

Table.1 Nutritional composition of fresh red Hibiscus rosa-sinensis flowers

\begin{tabular}{|c|c|}
\hline Nutrient & $\begin{array}{l}\text { Fresh Hibiscus rosa-sinensis flowers (per } \\
100 \mathrm{~g} \text { fresh weight) }\end{array}$ \\
\hline Moisture (\%) & 83.00 \\
\hline Protein (g) & 1.54 \\
\hline Fat (g) & 0.35 \\
\hline Total ash (g) & 1.40 \\
\hline Crude fibre (g) & 1.50 \\
\hline \multicolumn{2}{|l|}{ Vitamins } \\
\hline$\beta$-carotene $(\mu \mathrm{g})$ & 54.02 \\
\hline Vitamin C (mg) & 7.50 \\
\hline \multicolumn{2}{|l|}{ Minerals } \\
\hline Calcium (mg) & 4.32 \\
\hline Potassium (mg) & 236.45 \\
\hline Iron (mg) & 1.48 \\
\hline Zinc (mg) & 0.82 \\
\hline $\begin{array}{l}\text { Total antioxidant capacity (mg } \\
\text { AAE/100g) }\end{array}$ & 60.12 \\
\hline
\end{tabular}


Table.2 Development of value added products

\begin{tabular}{|l|c|c|}
\hline Name of the product & Ingredients used & $\begin{array}{c}\text { \% Level of incorporation of } \\
\text { hibiscus flowers }\end{array}$ \\
\hline Gulkand & Rose petals, sugar, honey & 10,25 and 50 \\
\hline Juice & Pineapple juice, sugar, citric acid & 10,25 and 50 \\
\hline
\end{tabular}

Table.3 Macro nutrient composition of developed products (per 100g/ml)

\begin{tabular}{|l|l|c|c|c|c|c|c|c|}
\hline Products & & $\begin{array}{c}\text { Moisture } \\
(\mathbf{\%})\end{array}$ & $\begin{array}{c}\text { Protein } \\
\mathbf{( g )}\end{array}$ & $\begin{array}{c}\text { Fat } \\
\mathbf{( g )}\end{array}$ & $\begin{array}{c}\text { Total } \\
\text { ash }(\mathbf{g})\end{array}$ & $\begin{array}{c}\text { Crude } \\
\text { fibre (g) }\end{array}$ & $\begin{array}{c}\text { Carbohyd } \\
\text { rate (g) }\end{array}$ & $\begin{array}{c}\text { Energy } \\
\text { (Kcal) }\end{array}$ \\
\hline \multirow{2}{*}{ Gulkand } & Control & 41.71 & 0.97 & 0.32 & 0.99 & 0.82 & 55.69 & 228.46 \\
\cline { 2 - 9 } & HGL1 & 41.91 & 0.94 & 0.28 & 0.24 & 0.80 & 55.66 & 227.86 \\
\hline \multirow{2}{*}{ Juice } & Control & 89.20 & 0.80 & 0.48 & 0.16 & 0.34 & 7.80 & 38.72 \\
\cline { 2 - 9 } & HJC3 & 90.40 & 0.56 & 0.23 & 0.13 & 0.26 & 6.90 & 31.91 \\
\hline
\end{tabular}

HGL1- Hibiscus gulkand 1 (10\%), HJC3- Hibiscus juice 3 (50\%)

Table.4 Mean sensory score for shelf life of hibiscus gulkand

\begin{tabular}{|c|c|c|c|c|c|c|c|}
\hline Products & Duration & Appearance & Color & Texture & Aroma & Taste & $\begin{array}{c}\text { Overall } \\
\text { acceptability }\end{array}$ \\
\hline \multirow{6}{*}{ Control } & Initial & 8.42 & 8.42 & 8.33 & 8.33 & 8.14 & 8.14 \\
\hline & $30^{\text {th }}$ day & 8.23 & 8.23 & 8.14 & 8.28 & 7.95 & 7.95 \\
\hline & $60^{\text {th }}$ day & 8.04 & 8.00 & 7.95 & 7.95 & 7.76 & 7.71 \\
\hline & F value & NS & NS & NS & NS & NS & NS \\
\hline & SEm \pm & 0.16 & 0.16 & 0.20 & 0.16 & 0.22 & 0.21 \\
\hline & CD at $5 \%$ & - & - & - & - & - & - \\
\hline \multirow{6}{*}{$\begin{array}{c}\text { HGL } 1 \\
(\mathbf{1 0 \%})\end{array}$} & Initial & 8.19 & 8.19 & 7.90 & 8.04 & 8.19 & 7.90 \\
\hline & $30^{\text {th }}$ day & 8.19 & 8.09 & 7.76 & 7.85 & 8.04 & 7.80 \\
\hline & $60^{\text {th }}$ day & 8.00 & 7.90 & 7.61 & 7.76 & 7.90 & 7.66 \\
\hline & F value & NS & NS & NS & NS & NS & NS \\
\hline & SEm \pm & 0.17 & 0.17 & 0.17 & 0.17 & 0.16 & 0.16 \\
\hline & CD at $5 \%$ & - & - & - & - & - & - \\
\hline
\end{tabular}

*Significant at 5\% level, NS- Non significant, HGL 1- Hibiscus gulkand 1 
Table.5 Population of bacteria, moulds, and coliforms in hibiscus gulkand

\begin{tabular}{|c|c|c|c|c|}
\hline \multirow[t]{2}{*}{ Products } & \multirow{2}{*}{$\begin{array}{c}\text { Duration } \\
\text { (Days) }\end{array}$} & \multicolumn{3}{|c|}{ Population of microorganisms $\left(\times 10^{2} \mathrm{cfu} / \mathrm{g}\right)$} \\
\hline & & Bacteria & Moulds & Coliforms \\
\hline \multirow{6}{*}{ Control } & Initial & 0.16 & 0.06 & Nil \\
\hline & $30^{\text {th }}$ day & 2.43 & 0.90 & 0.36 \\
\hline & $60^{\text {th }}$ day & 3.60 & 1.33 & 0.53 \\
\hline & F value & $*$ & $*$ & $*$ \\
\hline & SEm \pm & 3.86 & 1.24 & 0.38 \\
\hline & CD at $5 \%$ & 13.64 & 4.40 & 1.35 \\
\hline \multirow{6}{*}{$\begin{array}{l}\text { HGL1 } \\
(10 \%)\end{array}$} & Initial & 0.20 & 0.13 & 0.13 \\
\hline & $30^{\text {th }}$ day & 2.13 & 0.73 & 0.36 \\
\hline & $60^{\text {th }}$ day & 2.93 & 1.16 & 0.50 \\
\hline & F value & $*$ & $*$ & $*$ \\
\hline & SEm \pm & 3.39 & 1.31 & 0.57 \\
\hline & CD at $5 \%$ & 11.97 & 4.565 & 2.03 \\
\hline
\end{tabular}

*Significant at 5\% level, NS- Non significant, HGL1- Hibiscus gulkand 1

Table.6 Mean moisture content for shelf life study of hibiscus gulkand

\begin{tabular}{|c|c|c|}
\hline Products & Duration & Moisture content $(\%)$ \\
\hline \multirow{6}{*}{ Control } & Initial & 41.71 \\
\hline & $30^{\text {th }}$ day & 40.13 \\
\hline & $60^{\text {th }}$ day & 38.32 \\
\hline & F value & $*$ \\
\hline & SEm \pm & 0.21 \\
\hline & CD at $5 \%$ & 0.75 \\
\hline \multirow{6}{*}{$\begin{array}{c}\text { HGL1 } \\
(10 \%)\end{array}$} & Initial & 41.91 \\
\hline & $30^{\text {th }}$ day & 40.24 \\
\hline & $60^{\text {th }}$ day & 39.66 \\
\hline & F value & $*$ \\
\hline & SEm \pm & 0.26 \\
\hline & CD at $5 \%$ & 0.91 \\
\hline
\end{tabular}

*Significant at $5 \%$ level, NS- Non significant, HGL1- Hibiscus gulkand 1 
Fig.1 Microbial population of hibiscus gulkand (HGL1 10\%) on storage (per g)

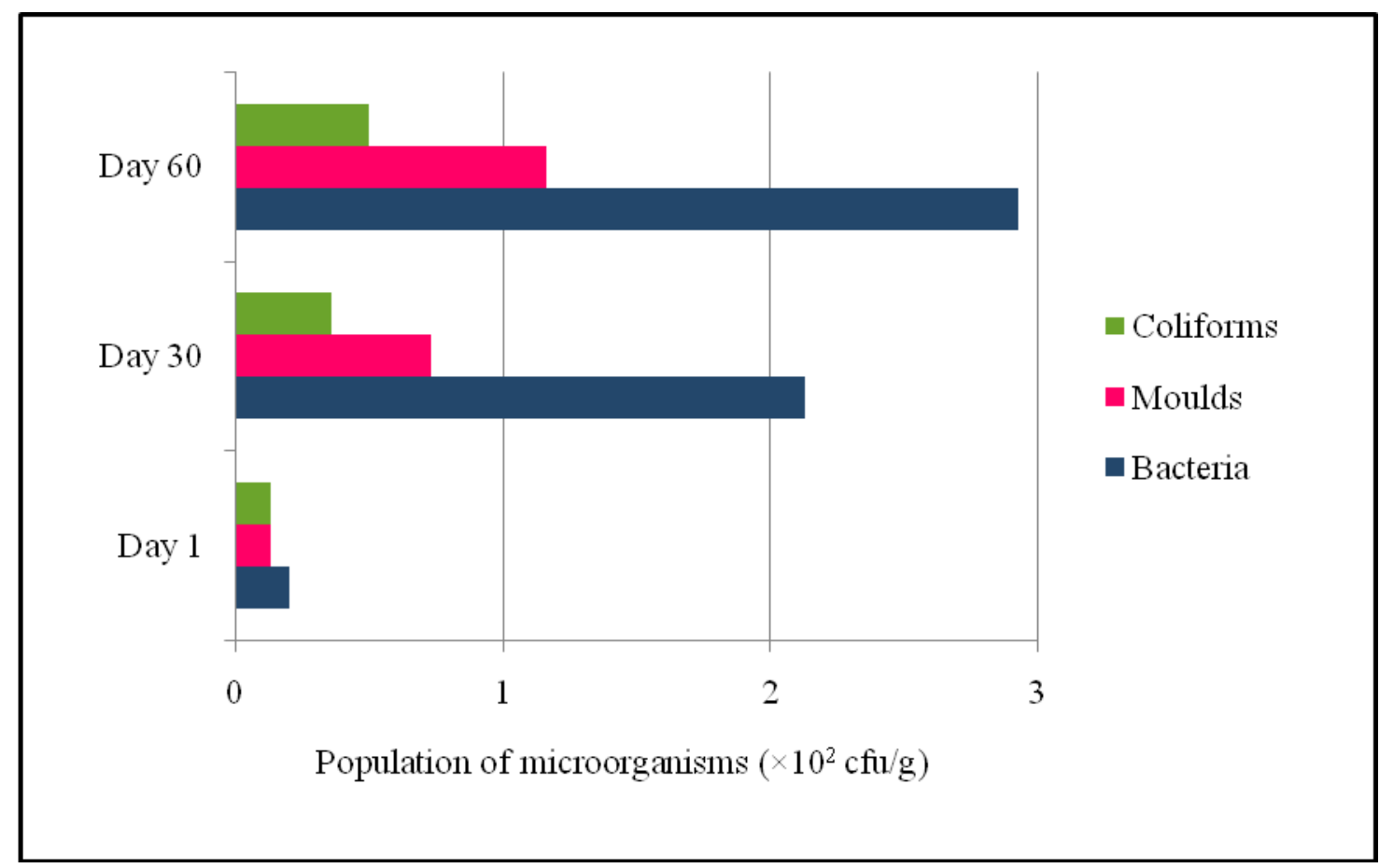

Fig.2 Mean moisture content of control and hibiscus gulkand during storage

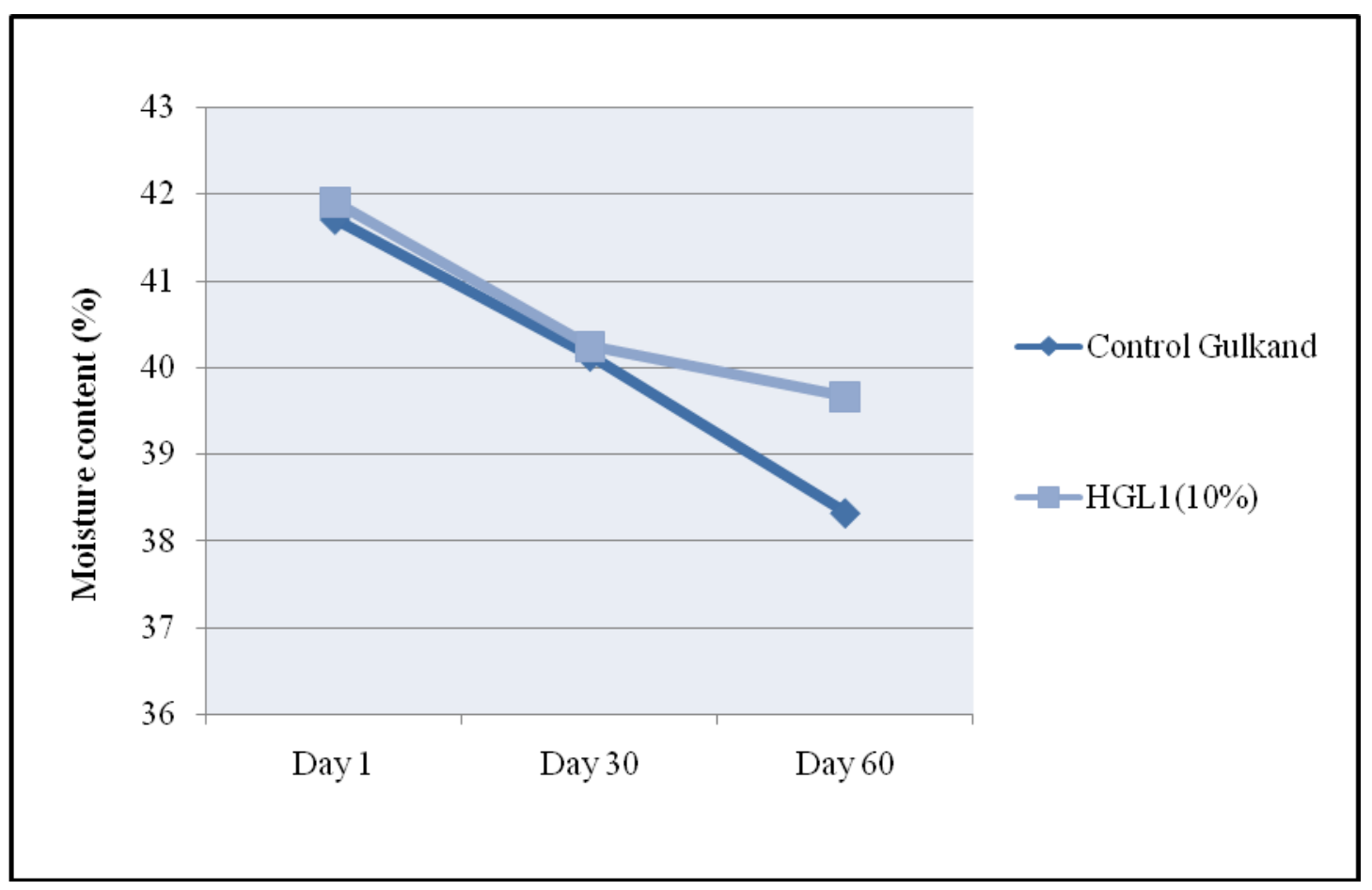

Comparing with HGL1, the control samples had higher population of microbes indicating that the microbial growth was more rapid in the control samples. Polyphenols, flavonoids and tannins present in HGL1 might be responsible for the observed antibacterial 
activity. These compounds are generally produced by plants as a mode of defense against microbial infections (Mak et al., 2013).

The changes in moisture content during storage ate depicted in Table 6 and Figure 2. The moisture content of both control and HGL1 gulkand decreased significantly during the 60 days storage period. The moisture content of control gulkand decreased from 41.71 on day 1 to 40.13 on day 30 and finally to 38.32 on $60^{\text {th }}$ day of storage. For HGL1 the moisture content was 41.91 initially, 40.24 on $30^{\text {th }}$ day and 39.66 on $60^{\text {th }}$ day of storage. The decrease in moisture content may be due to loss of moisture due to higher moisture content in the product compared o the storage environment creating a moisture gradient.

The study showed that hibiscus flowers are rich in phytochemicals. Acceptable value added products can be developed from hibiscus to enhance nutritional value and enrich therapeutic benefits. Thus, with further modification, hibiscus flowers can very well be exploited for value addition and consumption.

\section{Acknowledgement}

I am extremely thankful to the faculty of Department of Food Science and Nutrition, University of Agricultural Sciences, GKVK, Bangalore for their constant encouragement and guidance and kind help throughout my course of investigation.

\section{References}

A. O. A. C. 1980. Official methods of analysis of the Association of Official analytical chemists, Washington, D.C., pp 191-213.

Gopalan, C., Rama Sastri, B. V. and Balasubramanian, S. C. 2014. Nutritive value of Indian foods. National Institute of Nutrition, Indian Council of Medical Research. Hyderabad, India. 40-95.

Heau, W. R., Menzel, R. G., Roberts, H. and Freee, M.H. 1965. Methods of soil and plant analysis. Agriculture research service, Department of Agriculture, USA.

Jadhav, V.M., Thorat, R.M., Kadam, V.J. and Sathe, N.S. 2009. Hibiscus rosa sinensis Linn-"Rudrapuspa": A Review. $J$. Pharm. Res., 2(7): 1168-1173.

Kang, H.M. and Saltveit, M.E. 2002. Antioxidant capacity of lettuce leaf tissue increases after wounding. $J$. Agric. Food. Chem., 50: 7536-7541.

Khan, Z.A., Naqvi, S.A., Mukhtar, A., Hussain, Z., Shahzad, S.A., Mansha, A., Ahmad, M., Zahoor, A.F., Bukhari, I.H., Janjua, M.R.S.A. and Mahmood, N. 2014. Antioxidant and antibacterial activities of Hibiscus Rosa-sinensis Linn flower extracts. Pak. J. Pharm. Sci., 27(3): 469-474.

Lu, B., Li, M. and Yin, R. 2016. Phytochemical content, health benefits, and toxicology of common edible flowers: a review (20002015). Crit. Rev. Food Sci. Nutr., 56(1): 129-148.

Ranganna, S. 2002. Handbook of analysis and quality control for fruits and vegetable products. $2^{\text {nd }}$ Edn. Tata McGraw-Hill, Pub.Co.Ltd., New Delhi, pp. 84-86.

Tauber, H. and Kleiner, I. S. 1935. A method for the quantitative determination of ascorbic acid (vitamin C) content of various plant and animal tissues. J. Biol. Chem., 108: 363-570.

Pendawale, N.T., Atkare, V.G., Zinjarde, R.M., Rohini, N. and Shirke, S.S. 2015. Utilization of gulkand in the preparation of shrikhand. J. Soil Crop, 25(1): 168172.

Withy, L.M., Nguyen, T.T., Wrolstad, R.E., 
and Heather- Bell, D.A. 1993. Storage changes in anthocyanin content of red raspberry juice concentrate. J. Food Sci., 58: 190-192.

Kimura, K., Ida, M., Yosida, Y., Ohki, K., Fukumoto, T. and Sakui, N. 1994. Comparison of keeping quality between pressure-processed jam and heatprocessed jam: changes in flavor components, hue, and nutrients during storage. Biosci.

Biotechnol. Biochem., 58(8): 1386-1391.

Touati, N., Tarazona-Díaz, M.P., Aguayo, E. and Louaileche, H. 2014. Effect of storage time and temperature on the physicochemical and sensory characteristics of commercial apricot jam. Food Chem., 145: 23-27.

Sindumathi, G. and Amutha, S. 2014. Processing and quality evaluation of coconut based jam. IOSR J. Environ. Sci. Toxicol. Food Technol., 8(1): 1014.

Mak, Y.W., Chuah, L.O., Ahmad, R. and Bhat, R. 2013. Antioxidant and antibacterial activities of hibiscus (Hibiscus rosa-sinensis L.) and Cassia (Senna bicapsularis L.) flower extracts. J. King Saud Univ. Sci., 25(4): 275-282.

\section{How to cite this article:}

Aishwarya Bahuguna, K.G. Vijayalaxmi and Suvarna, V.C. 2018. Formulation and Evaluation of Fresh Red Hawaiian Hibiscus (Hibiscus rosa-sinensis) Incorporated Valued Added Products. Int.J.Curr.Microbiol.App.Sci. 7(08): 4282-4290. doi: https://doi.org/10.20546/ijcmas.2018.708.449 